\title{
Research on the development countermeasures of freight forwarding logistics under container liner alliance
}

\author{
Gao Wei \\ Qingdao ocean shipping mariners college logistics and shipping management department, \\ Shandong Qingdao 266071
}

\begin{abstract}
Key words: freight forwarding; logistics; liner alliance; countermeasures research
Abstract: With the development of international economic and trade, the international shipping industry has also been rapid development, especially the development of marine container freight business is inferior, as one of the shipping industry, freight forwarding industry has also been developed opportunities. The international shipping market, especially the container liner shipping companies merge each other, form alliances, have a certain impact on the freight forwarding logistics industry, and the competition is very fierce, In the new situation of the liner alliance, how to develop the freight forwarding physical business, and strengthen the countermeasures research has become the focus of many small and medium-sized freight forwarders logistics companies.
\end{abstract}

\section{Introduction}

International shipping industry generally refers to the marine cargo transport industry, the international shipping market is mainly composed of dry bulk transport market, container transport market and tanker transportation market. Freight forwarding logistics industry is a part of shipping physical services in the international shipping market. The development of modern logistics services is the direction of freight forwarding industry, but China's freight forwarding industry also maintains in the traditional logistics services such as cargo booking, booking space and other logistics services, enterprises mainly small and medium-sized, fierce competition. With the combination of container liner companies and the formation of liner alliances, especially the recent changes of the new and old alliances, provides great opportunities and challenges to the development of the freight forwarding logistics industry, and has a huge impact. How to develop freight forwarding logistics business in the new situation is an important strategic task for freight forwarding logistics enterprise to adapt to the market development and improve the core competitiveness of freight forwarding enterprises.

\section{International shipping industry and freight forwarding industry}

\subsection{International shipping industry}

The international shipping industry is the international shipping market, also known as the shipping market. Divided into broad and narrow shipping markets. The narrow sense of shipping market refers to the market of ship transport transaction for the owner of the ship which provides the ship for the carriage by sea, or the charterer who needs the ship to be transported or the charterer who needs the ship to engage in the shipping, also known as the ship and the goods supply and demand exchange market. The broad shipping market includes not only the above market, It also includes the crew labor market, shipping information market, shipping financial market, ship trading market, shipbuilding market, ship recycling market, ship repair market and so on. Generally speaking, the shipping market owners should include the international dry bulk transport market, container transport market and tanker transport market.

Shipping service industry is the basic service system which mainly includes port loading and unloading, warehousing logistics, ship agency, freight forwarding, ship supply and crew service, etc. 


\subsection{Freight forwarding logistics}

In China, the definition of logistics in the people's Republic of China national standard logistics terms refers to the flow of goods from the supply to the receiving place, according to the actual needs, combine the basic functions of the transportation, storage, handling, handling, packaging, distribution processing, distribution, information processing to achieve the user requirements.

As the competent department of the international freight forwarding industry, the Ministry of commerce of China is engaged in the international freight agency business as an agent for the international freight forwarders, it is defined as the entrustment of the international freight forwarder to accept the consignee, consignor or its agent of the import and export goods, and conduct the relevant business in the name of the principal, and collect the agency fees or commissions. The international freight forwarder, as an independent operator, is engaged in the international freight forwarding business, which means that the international freight forwarding industry accepts the entrustment of the consignee, consignor or its agent, issuing the transport document, performing the transportation contract and collecting the freight and service charge. The international freight forwarders international freight forwarding business scope includes including but not limited to the canvassing, booking space ( including chartering, charter, package board, package cabin ), shipping, stowage, exchange, repair documents, warehousing, distribution, distribution, transit, container package and so on.

In the container transport business, the most important is the container liner shipping business, as the freight forwarding industry of the shipping service industry has a close relationship with the container liner shipping industry. At present, the proportion of container freight transport in the freight forwarding logistics industry is also more and more large.

\section{The status of the alliance of container liner companies}

\subsection{The beginning of the alliance}

The alliance of container liner companies began around 1990. The cancellation of the European liner conference marks the end of the era of the EU liner market and the liner conference, the market pattern has changed, the reference price of the market no longer exists, the environment of container freight transport market has changed greatly. In order to improve the competitiveness, the members of the original container liner conference began to adopt the alliance way to hedge the fierce market competition and improve the competitiveness.

\subsection{The status of the alliance of container liner companies}

As of early 2017, the container liner shipping market has four major: 2M alliance, O3 alliance, G6 alliance, and CKYHE alliance. With the merger of COSCO and China shipping group, the merger of Japan KLINE, MOL and Japan mail liner, and the merger wave of other companies, especially the combined period of $\mathrm{O} 3$ and CKYHE alliance is close to the end, The original container liner company alliance has a new change. There are currently three major alliances: $2 \mathrm{M}$ alliance and OCEAN Alliance, Hapag-Lloyd, Hanjin Shipping, Yang Ming shipping, Mitsui O.S.K. Lines, NYK and K-LINE constitute the third alliance.

With the formation of the liner alliance, the container transportation market has undergone drastic changes, and the competition between shipping enterprises is becoming more and more fierce. These all have higher requirements for the freight forwarding industry in our country, to adapt to the new situation, to this, the development countermeasures of freight forwarding logistics are more and more important.

\section{Research on the development countermeasures of freight forwarders logistics industry}

\subsection{Innovate the service concept of the logistics industry and improve the level of professional comprehensive service}

The traditional service concept of freight forwarding industry, enterprises only rely on the 
canvassing, booking space to earn service fees or spreads, has not met the requirements of the new situation of the liner alliance, At present, the price of liner companies is more transparent, the competition among shipping companies is fierce, and the freight rate space for freight forwarding enterprises is smaller and smaller. We must innovate the service concept of freight forwarding industry, rely on the development of modern logistics, meet the requirements of customers, in addition to providing traditional services such as canvassing, booking, customs declaration, short-distance transportation, etc. We should provide professional comprehensive services according to the specific requirements of each customer, provide comprehensive services from international trade contracts to letters of credit, raw materials procurement, warehousing and distribution, document production, cargo transportation, booking space, customs declaration and information technology information, etc.

\subsection{Develop new customer resources and constantly develop new customers}

The customers of freight forwarding logistics enterprises are divided into direct source customer and peer supply customers, the direct source customers are domestic and foreign international trading companies or import and export processing enterprises, and the peer supply customers are mainly domestic and foreign freight forwarding logistics industry peers. In the new situation of the liner alliance, the competition between the liner companies is fierce, the price is more transparent, the freight forwarding logistics companies need to develop new customers, compete with the liner alliance company, and strive for more supply customers. The development of new customers can use the exhibition, advertising newspapers, industry magazines, industry websites, various communication groups and old customers to introduce the methods. In the development of new customers, we also should to have customer relationship management to their customers . Provide professional services according to customer requirements to improve customer satisfaction.

\section{3 establish the freight forwarding logistics alliance, improve the discourse right}

In view of the new changes of container liner company alliance, freight forwarding logistics enterprises, especially small and medium-sized enterprises, should join together to form a freight forwarding enterprise alliance, using their advantages and resources to form a share. At the same time, it can also have a higher voice in the dialogue with the liner alliance, and it can provide the customers with cheaper price and provide higher comprehensive service level.

\subsection{Develop e - commerce and build e - commerce platform}

In the face of the container liner company alliance, freight forwarding logistics enterprises need to change the existing logistics service mode, using modern information technology, especially the rapid development of modern e-commerce, to build a unified e-commerce business management platform and system, freight forwarding logistics enterprises, port logistics enterprises, container stations, warehouses, warehousing and customs declaration and quarantine inspection departments together to jointly build a unified electronic commerce platform, use a unified modern information system, transport by sea, highway, railway and air transport in an electronic commerce information system, optimize the whole logistics information system to provide customers with quality service.

\subsection{Expand the new market of freight forwarding under " internet plus" and expand the development space}

Facing the container liner alliance, in the new economic era of " internet plus ", freight forwarding logistics enterprises need to develop new logistics market, expand marketing channels, develop new business space such as multinational e - commerce, use modern information technology, use the good line and offline these two resources, update freight forwarding logistics facilities equipment, provide modern logistics service, build the whole chain of e - commerce service.

\subsection{Developing modern financial services to avoid business risks}

In the case of the liner alliance, the freight forwarding logistics enterprises will have a great risk in the process of business processing, take greater responsibility, in order to avoid the risk in the business process, freight forwarding logistics enterprises can provide modern financial services, provide financing services for customers, using their own regulatory advantages in the import and export, transportation, warehousing and other links, with the bank and other financial institutions to 
provide customers with the mortgage logistics financial services and so on. At the same time, in the process of the business, implement the " imprest" system, let the customer pay a certain amount in advance, offset the related expenses paid by the freight forwarding company in the process of business processing, and reduce the business risk.

\subsection{Strengthening the training of talent team in freight forwarding logistics industry}

Facing the new situation of container shipping alliance, freight forwarding logistics enterprises should organize the professional learning and business training of the employees, carry out on-the-job training, meet the development requirements of the liner alliance and modern information technology, and vigorously carry out the freight forwarding logistics professional talent team training work. They can cooperate with the undergraduate or higher vocational colleges, participate in the vocational education of the colleges and universities in a fixed class way, and train the specialized talents required by the logistics development of freight forwarders. At the same time, also with institutions and other research institutions to strengthen cooperation, carry out freight forwarding logistics research work.

\section{Concluding remarks}

To sum up, with the development of international shipping market especially the container liner shipping market, freight forwarding logistics industry as a part of shipping services, especially small and medium freight forwarding enterprises should strengthen research, propose business development solutions for the new situation, promote the development of freight forwarding logistics industry, at the same time, provide high-quality service for customers, and promote the development of international shipping and international trade.

\section{Reference}

[1] Ma Wenjun, Research on the network channel mode of international freight forwarding enterprises in China [ j ] Journal of Commercial Economics, 2010 ( 33 )

[2] Li Zhenshan. The influence and countermeasures of e - commerce on logistics industry [ j ]. Business Modernization, 2006 ( 3 )

[3] Wei Yongqing, Liu Peide. The problems and countermeasures of logistics operation of small and medium - sized enterprises under e - commerce environment [ j ]. Rural Economy, 2007 ( 4 )

[4] Tang Yongming. The influence of the development of e - commerce on the development of logistics in China [ j ]. Science and Technology Information, 2010 ( 32 )

[5] Wang Wuya. The dilemma and strategic transformation of international freight forwarders, 2008 ( 27 )

[6] Tang Shaolin, Qiao Tingting. Developing logistics finance and strengthening logistics integration [ j ] Logistics Technology, 2006 ( 2 ), No.2 